\title{
A philosophical and socio-historical defense of the secular, democratic and mixed economic state
}

Ben Geoffrey A S

Madras Christian College, Chennai, Tamil Nadu, India

Corresponding author : email:bengeof@gmail.com phone:+919940469238

\begin{abstract}
An inquiry into the philosophical foundations of a secular, democratic welfare state has been carried out. The necessity of such a work arises because a deeper philosophical framework is necessary for clarity to define secularism of whether secularism means pluralism and the tolerance of diversity for a greater end or the absolution of atheistic humanism and its intolerance toward other worldviews. Self-interest theory of human behavior is discussed as the basis for requiring reduction is power concentration and how such reductions in power concentrations is achieved through a democratic mixed economic state is discussed. The selfinterest theory of human behavior says that human action is driven by self-interest which is automatic, natural and viscerally compelling while our obligation to others is a more thoughtful process of deliberation over morality. However by the common psychological biases such as confirmation and self-serving biases, our individualism overpowers our morality. Therefore it is concluded that while a Democratic mixed economic state is not the idealism of all that power can achieve if we did everything right in an ideal world but rather what we need to prevent the worst from happening in the real world by the dangers of power concentrations and self-interest seeking individuals and considering we live in the real world than in the ideal world we should take it as the best possible solution to our political and economic thought
\end{abstract}




\section{Introduction}

An inquiry into the philosophical foundations of a secular, democratic welfare state has been carried out. The necessity of such a work arises because a deeper philosophical framework is necessary for clarity to define secularism regarding which there is plenty of discussion and debate[1-3] of whether secularism means pluralism and the tolerance of diversity for a greater end or the absolution of atheistic humanism and its intolerance toward other worldviews[4,5]. Skepticism is also expressed regarding democratic institution [6,7], this necessitates the rationale for democratic state is explored and faith in democracy be restored. In history, Democratic institutions have come about to avert the dangers of excessive power concentration in the hands of few individuals. Based on the self-interest theory of human behavior [8] people in power are more likely to use the political power vested with them on public faith in selfserving ends than in the interest of the common good. The self-interest theory of human behavior also means that the dangers of excessive power concentrations that come by economic wealth concentrations also have to be averted. While self-interest is the driver of humanbehavior and therefore wealth creation, individuals more economically powerful are more likely to exploit in their self-interest those that are not. Therefore a welfare state should protect the interest of those economically weak and marginalized. These are matters of detailed elucidation in the present work. 


\section{Genealogy of the State}

The basis or the necessity of the state is that man is born a social animal and left to himself he is not self sufficing as Aristotle explains 'The proof that the state is a creation of nature and prior to the individual is that the individual, when isolated, is not self-sufficing; and therefore he is like a part in relation to the whole. But he who is unable to live in society, or who has no need because he is sufficient for himself, must be either a beast or a god: he is no part of a state.' [9]

The group is more powerful than the individual, and the organized unity of many groups that form a State working toward a common end is based on the old adage Unity is Strength. For if one does not believe in the power of organized groups over the individual then he/she is trumped by the power of the group over the individual just like how organized civilizations replaced nomads [10]. Swami Vivekananda says 'I am thoroughly convinced that no individual or nation can live by holding itself apart from the community of others, and wherever such an attempt has been made under false ideas of greatness, policy or holiness - the result has always been disastrous to the secluding one.' [11]

Hence it is evident that the state is a creation of nature, and that man is by nature a political animal.

\section{Why a Secular Union}

According to Aristotle in his Politics every state is a community of some kind, and every community is established with a view to some good; for mankind always act in order to obtain that which they think good. 'All well-being' says Aristotle 'consists of two things: one of them is the choice of a right end and aim of action, and the other the discovery of the actions which are means towards it.' [9] According to Aristotle Eudaimonia is the ultimate ends to which human beings direct our action. Eudaimonia is a Greek word which means wellness and flourishing. Since human beings are physical, mental and spiritual beings, in all our actions we are seeking our wholesome physical, mental and wellness and flourishing. These actions are empowered by the collective power of the state. These actions must also be guided by the path of virtue, for according to Socrates human wellness is achieved by following the path of Virtue for he says in 
the Apology 'Virtue doesn't come from money, but money and all other good things come from virtue to men both in private and in public.'[12] Thus a secular state or union is a union of the public or civil sphere for the sake of collective strength toward the end of material flourishing of the state governed by natural justice which is moral laws evident to plain conscience. The pursuit of the private sphere of religion toward the end of spiritual wellness and flourishing is largely free of the state's control and in some cases governed by separate laws for different religious groups. This union is only possible for those whose theological intolerance does not translate to civil intolerance according to the social contract theory of Thomas Hobbes. For those who cannot distinguish theological and civil intolerance this Union of diversity is not possible but for those who can it is commended as a Union of Strength toward the flourishing and wellness of the state and its entire people. The secular principle of separation of state and religion in modernity goes back to the protestant reformation where the reformers rediscovered the danger of power concentration that came by politics directly sanctioned by religious authorities. If men are naturally religious as in past history and their worldview is informed by religion then priests of religion become the chief influences of men's lives, ideas and morality and political power can get a direct control of people's ideas, morality and sense of common good and make it a subservient to the personal good of the ruling aristocracy by making religious influencers and authorities beneficiaries to political power and thereby amputating the social arm in a religious society that is best positioned to speak truth to power when power corrupts truth and justice. Among the many world nation states that have adopted the secular principle, the Indian Union also currently reflects these principles of secularism and pluralism enshrined in its constitution. The first Indian cabinet of India was ecumenical in that it had members from 5 different religions and 2 atheists [13]. For Sardar Vallabhai Patel hailed as the Iron Man of India who was responsible for the political integration of Indian Union in one his letters to the princely states wrote 'We are at a momentous stage in the history of India. By common endeavor, we can raise the country to new greatness, while lack of unity will expose us to unexpected calamities. I hope the Indian States will realize fully that if we do not cooperate and work together in the general interest, anarchy and chaos will overwhelm us all great and small, and lead us to total ruin......let it be our proud privilege to leave a legacy of mutually beneficial relationship which 
would raise this sacred land to its proper place amongst the nations of the world and turn it into an abode of peace and prosperity.'[14]

\section{Why a Democratic State}

There are different forms of government such as an aristocracy which is the rule of most learned most noble or simply the best according to Aristotle. Closest to this concept in modernity is meritocracy. Another form of government is a theocracy which is the rule of the religious elite of the society because of its sway with the masses and thereby by controlling the ruling aristocracy. This can be thought of as a version of aristocracy while monarchy is the absolutist rule by King and if the King claims to be religious ordained we have a theocratic monarchy. The Political idealism of Plato is the rule of a philosopher king in who perfect virtue to will the good, perfect wisdom to know what is the good and perfect power to bring it to fruition is embodied. However all idealism is far from practical. In the real world people are driven by self-interest that according to Don Moore et al self-interest in automatic, natural and viscerally compelling while our obligation to others is a more thoughtful process of deliberation over morality [8]. However by the common psychological biases such as confirmation and self-serving biases, our individualism overpowers our morality [15]. Sir Roger Scruton an influential British Philosopher says 'the very fact that - Intellectuals are naturally attracted by the idea of a planned society, in the belief that they will be in charge of it'. [16] Therefore if self-interest theory of human behavior is true then all power vested with an individual by public faith in expectation of his service of the common good fails to serve the common good and also empowers the self-seeking human nature to serve the personal good. Thoughts on self seeking or selfish human nature find its roots in tradition Christian thought on intrinsic human corruption. The medieval philosopher Thomas Aquinas attempts to prove this by an argument from experience where he says that the very fact we are tempted by evil proves that we have an innate desire for evil, for we cannot be tempted by what we do not have a desire for[17]. Therefore the human will being more predisposed to evil than good when empowered by power is further empowered to serve selfinterest than the common good [18]. Thus Protestant Christian thought to which much these thoughts on human depravity can be traced to, regards power as a necessary evil, necessary 
because without the rule of power there is chaos and order is lacking but considering the corruption of human nature Protestant political thought has advocated limited government and reduction in power concentrations [19-20]. Post protestant reformation much of the emergence of democratic thought and states can be traced back to reformations rediscovery of the dangers of power concentrations and those lessons are perennially significant and they are as significant for us today as it was for them then and we must not repeat the mistakes of history.

Thus the First Prime Minister Jawaharlal Nehru of Indian Democracy reminded the country of the dangers of power concentrations and commended the adhering to democratic institutions and said 'If we adhered to the democratic state structure and encouraged co-operative enterprises, many of the dangers of regimentation and concentration of power might be avoided.'[21] Democracy though has its downsides when ignorant opinion of the masses begins to influence state policy and order, folly reigns supreme. Dr.B.R.Ambedkar the chief architect of the Indian constitution himself was bothered about this problem; he says 'I am no believer in democracy as an ideal to be pursued in all circumstances and all times. In this country we have a democracy but it is a democracy which has ceased to exercise its intelligence. Democracy must learn that its safety lies in having more than one opinion regarding the solution of a particular problem, and in order that people may be ready to advice with their opinion, democracy must learn to give a respectful hearing to all who are worth listening to.' [22] Therefore to incorporate the pros of an aristocracy of rule by best informed opinion into a democracy, a free press and academic freedom should exist, for the opinion of the learned and erudite to inform the opinion of the masses just as the Article 19 of the constitution of India allows freedom of opinion and expression.

\section{Why A Mixed Economic State}

The two major economic systems in modern societies are capitalism and socialism. Capitalism refers to the private ownership of goods and property where each man is unto his own and competition is said to bring out the best in him. Socialism though refers to the common ownership and distribution of goods and property. Capitalism is usually justified on the grounds 
of individualism, for example in a class it is unfair to mark or reward everyone the same when their actual performance of each individual was different. Socialism on the other hand is justified based on collectivism, for example we consider society as whole human body with each part performing different functions which are equally important for the proper function of the entire human body. In this hyper-individualistic age it is hard for people to acknowledge collectivism, so we arrange an apologia for collectivism given by the philosopher John Stuart Mill. He says 'No person is an entirely isolated being; it is impossible for a person to do anything seriously or permanently hurtful to himself, without mischief reaching at least to his near connections, and often far beyond them. If he injures his property, he does harm to those who directly or indirectly derived support from it, and usually diminishes, by a greater or less amount, the general resources of the community. If he deteriorates his bodily or mental faculties, he not only brings evil upon all who depended on him for any portion of their happiness, but disqualifies himself for rendering the services which he owes to his fellow-creatures generally; perhaps becomes a burden on their affection or benevolence. Hence goes on to say - that the mischief which a person does to himself, may seriously affect, both through their sympathies and their interests, those nearly connected with him, and in a minor degree, society at large.'[23] Thus we can safely say that there are no individual actions whose consequence is entirely limited to the individual, they go beyond the individual to deter or advance the common good of society.

The design of nature seems to be neither purely capitalistic nor purely socialistic, for we are neither individuals with no need for community neither are we a lump sum whole. We are individuals who are a part of the larger whole performing different functions toward a common end. The extremes of capitalism and socialism both lead to the dangers of power concentration and hence the golden mean or a practical middle, a mixed economy can be adopted as a solution. They are both lessons of history that if a democratic welfare state was not in place extremely powerful capitalists will grow arrogant and haughty to oppress the weak which will lead to steady polarization of society often leading to insurrections, civil wars and instability. The French revolutions were a situation where peasants (serfs) overthrew their feudal (capitalistic) lords cause of exploitation that came by wealth concentration. However since self-interest is the 
driver of human behavior, self-interest is also the best driver for economic wealth creation. After the World War II the world was divided into the Western or the Capitalistic bloc and the Eastern or Socialistic bloc and history showed that the Western bloc was more economically successful such that Eastern Germany renounced its communism and brought down the dividing Berlin wall to unite with the more successful capitalistic west. Hence as Albert Einstein a German insider observes, capitalism is more successful because human beings are driven by self-interest rather than a dutiful obligation to the common good, he says "It's no accident that capitalism has brought with it progress, not merely in production but also in knowledge. Egoism and competition are, alas, stronger forces than public spirit and sense of duty."[24] However a completely socialistic state suffers from the same dangers of power concentrations as state or common ownership, production and distribution wealth means all power is concentrated in the head of the state and hence completely socialistic state is state capitalism. The dangers from such power concentration also history has shown to be grave. These are lessons learnt from the Western and Eastern Bloc [25]. Hence in a mixed economy modern Indian union's founding fathers put this greed to providential use, they allow these greedy accumulators to amass wealth and progress however a welfare state levies a tax proportional to their greed and uses it in welfare schemes directed toward the marginalized to enable them to get out of poverty and escape the perils of being part of the weaker section of society because of which they are exploited.

While a Democratic mixed economic state is not the idealism of all power can achieve is we did everything right in an ideal world but it's what we need to prevent the worst from happening in the real world by the dangers of power concentration and a world filled with self-interest pursuing individuals and considering we live in the real world than in the ideal world we should take it as the best possible solution to our political and economic thought. 


\section{References}

1. Taylor, Charles. "How to define secularism." In Religious Rights, pp. 541-560. Routledge, 2017.

2. De Roover, Jakob. Europe, India, and the limits of secularism. New Delhi: Oxford University Press, 2015.

3. Ibrahim, Nur Amali. "Questioning the New Secularism of the West." Politics, Religion \& Ideology 18, no. 1 (2017): 107-109.

4. Bader, Veit. "Religious pluralism: Secularism or priority for democracy?." Political theory 27, no. 5 (1999): 597-633.

5. Cimino, Richard, and Christopher Smith. "Secular humanism and atheism beyond progressive secularism." Sociology of Religion 68, no. 4 (2007): 407-424.

6. Brouwer, Peter, and Klaas Staal. "The Democracy of the Future: Do Voters Want It?" Homo Oeconomicus 35, no. 1-2 (2018): 133-141.

7. Kellner, Douglas. Television and the Crisis of Democracy. Routledge, 2018.

8. Moore, Don A., and George Loewenstein. "Self-interest, automaticity, and the psychology of conflict of interest." Social Justice Research 17, no. 2 (2004): 189-202.

9. Aristotle, and Benjamin Jowett. —Book One.\| Politics, Batoche Books, 1999, p. 6.

10. Maisels, C. K. (2016). Emergence of civilization: from hunting and gathering to agriculture, cities, and the state ... of the near east. Taylor \& Francis.

11. Nehru, Jawaharlal. - Consolidation of the British Rule and the Rise of the Nationalist Movement.|l Discovery of India, Oxford University Press, 1989, p. 338.

12. Riddell, James, ed. The Apology of Plato. Clarendon Press, 1867.

13. Guha, Ramachandra. - India After Gandhi .॥ India After Gandhi .

14. Grover, Verinder, and Sardar Vallbhbhai Patel. —No Impassable Barriers .॥ Political Thinkers of Modern India, vol. 18, Deep \& Deep Publications, p. 23.

15. Evans, J., and R. Pohl. "Cognitive Illusions: A Handbook on Fallacies and Biases in Thinking, Judgement and Memory." (2012). 
16. Roger, Scruton. "Fools, Frauds and Firebrands: Thinkers of the New Left." (1985).

17. Aquinas, Thomas. Summa theologica. Authentic Media Inc, 2012.

18. Luther, Martin. The bondage of the will. Hendrickson Publishers, 2008.

19. Lloyd-Jones, David Martyn. Romans: An Exposition of Chapter 13: Life in Two Kingdoms. Banner of Truth Trust, 2002.

20. Brody, Samuel Hayim. "Prophecy and Powerlessness." Political Theology (2019): 1-13.

21. Biswas, Suptendu P. Assorted city: Equity, justice, and politics in urban services delivery. SAGE Publications India, 2015.

22. Keer, Dhananjay. —Labour Leader.\| Dr.Ambedkar : Life and Mission, Popular Prakashan, pp. 298-299.

23. Mill, John Stuart. - Of the Limits to the Authority of Society over the Individual.\| On Liberty, Batoche Books, 2001, p. 74

24. Rowe, David, et al. - Einstein on Politics.\| Einstein on Politics, Princeton University Press, p. 419.

25. Leffler, Melvyn P., and Odd Arne Westad, eds. The Cambridge History of the Cold War. Vol. 1. Cambridge University Press, 2010. 